Cafer Kaplan

Coşkun Araz

Selim Candan

Arash Pirat

Pınar Zeyneloğlu

Ali Ayhan

Gülnaz Arslan

\section{Evre III-IV Over Kanseri Nedeniyle Sitoredüktif Cerrahi Geçiren Hastalarda Postoperatif Yoğun Bakım Gereksiniminin Ön Belirleyicileri}

\author{
Predictors of Intensive Care Unit Admission \\ Following Cytoreductive Surgery For Stage III-IV \\ Ovarian Carcinoma
}

Geliş Tarihi/Received: 23.08.2012

Kabul Tarihi/Accepted: 17.09.2012

Türk Yoğun Bakım Derneği Dergisi, Galenos Yayınevi tarafindan basilmıștı.

Journal of the Turkish Society of Intensive Care, published by Galenos Publishing.

ISNN: 1300-5804

Cafer Kaplan, Coşkun Araz (凶), Selim Candan, Arash Pirat, Pınar Zeyneloğlu, Gülnaz Arslan

Başkent Üniversitesi Tıp Fakültesi, Anesteziyoloji Anabilim Dalı, Ankara, Türkiye

\section{Ali Ayhan}

Başkent Üniversitesi Tıp Fakültesi, Kadın Hastalıkları ve Doğum Anabilim Dalı, Ankara, Türkiye

E-posta: arazcoskun@yahoo.com

Tel.: +903122126868
ÖZET Amaç: Over kanseri hastalarında preoperatif ve intraoperatif verilerin postoperatif yoğun bakım (YB) intiyacının tahmininde kullanılabileceğinin gösterilmesi. Gereç ve Yöntem: Çalışmamızda Ocak 2007Aralık 2009 tarihleri arasında sitoredüktif cerrahi uygulanan tüm hastaların verileri geriye dönük olarak tarandı. Demografik özellikler, eşlik eden hastalıklar, operasyon öncesi laboratuvar bulguları, operasyon sırasındaki veriler ve operasyon sonrası YB'a kabulü/kabul edilmeyişine dair veriler kaydedildi.

Bulgular: Çalışmamızda ilerlemiş over kanseri nedeniyle sitoredüktif cerrahi uygulanan 122 hastadan 58'inin (\%48) operasyon sonrası YB'a kabul edildiği görüldü. Yoğun bakıma alınmayan grupla karşılaştıııldığında YB'a kabul edilen hastalarda; kronik obstrüktif akciğer hastalığı, intraoperatif hipotansiyon ve taşikardi, kan ürünleri transfüzyonu intiyacı daha sıktı, yașları, ortalama vücut kitle indeksleri daha yüksekti. Operasyon öncesi daha düşük bir oksijen satürasyonuna sahiptiler ve intraoperatif daha fazla sIVI verilmesi gerekti. İkili lojistik regresyon analizi bu hastalarda; yaș $(O R, 1,1 ; p=0,036)$, ASA skoru $(O R, 6,2 ; p=0,044)$, intraoperatif sinüs taşikardisi olması (OR, 8,6; $p=0,013)$, operasyon sırasında transfüzyon gerekliliği $(\mathrm{OR}, 7,7 ; \mathrm{p}=0,026)$ ve preoperatif oksijen satürasyonunun (OR, 1,3; $p=0,050)$, YB'a kabul edilmenin ön belirleyicileri olduğunu gösterdi. Sonuç: Bulgular göstermektedir ki, ileri yaş, yüksek ASA sınıfı ve preoperatif düșük oksijen satürasyonu ile intraoperatif sinüs taşikardisi gelișmesi ve kan ve kan ürünü transfüzyonu yapılması bu hasta grubunda postoperatif yoğun bakım intiyacı için bağımsız risk faktörleridir.

Anahtar Kelimeler: Over kanseri, yoğun bakım, ön belirleyiciler
SUMMARY Objective: To demonstrate that preoperative and intraoperative data of ovarian carcinoma patients can be used for prediction of postoperative ICU admission.

Material and Method: The charts of all patients with ovarian carcinoma who underwent cytoreductive surgery from January 2007 to December 2009 were reviewed. The data recorded were demographic features, coexisting disease, preoperative laboratory findings, intraoperative data, and admission/no admission to ICU postoperatively. Results: Out of 122 patients who underwent cytoreductive surgery for advanced ovarian carcinoma, 58 patients (48\%) required ICU admission postoperatively. Compared with the group not admitted to ICU, the patients with ICU admission were significantly different regarding the frequency of chronic obstructive pulmonary disease, occurrence of intraoperative hypotension and sinus tachycardia,

intraoperative need for blood products and total fluid transfusion, preoperative oxygen saturation, mean age and mean body mass index (BMI). Binary logistic regression analysis revealed that age $(O R, 1.1 ; p=0.036)$, ASA score $(\mathrm{OR}, 6.2 ; p=0.044)$, occurrence of intraoperative sinus tachycardia (OR, 8.6; $p=0.013$ ), need for intraoperative transfusions $(O R, 7.7 ; p=0.026)$ and preoperative oxygen saturations $(\mathrm{OR}, 1.3$; $p=0.050$ ) were the predictors of ICU admission in these patients.

Conclusion: The results suggest that age, high ASA scores, low preoperative oxygen saturations, intraoperative sinus tachycardia and blood product transfusions were predictors of ICU admission following cytoreductive surgery for ovarian carcinoma.

Key Words: Ovarian carcinoma, intensive care unit, predictors 


\section{Giriş}

Jinekolojik malignitesi bulunan hastalarda sitoredüksiyon veya evreleme amacıyla yapılan cerrahilerde hastaya veya cerrahi nedenlere bağlı olarak morbidite ve mortalite gözlenebilir. Cerrahi öncesinde veya sırasındaki malignitenin yaygınlığı, medikal tedavi uygulamaları ve bunların komplikasyonları, eşlik eden organ ve sistem yetmezlikleri, yapılan cerrahinin büyüklüğü ya da cerrahi komplikasyonlar gibi nedenlerle hastaların postoperatif dönemde yoğun bakıma (YB) alınmaları gerekebilir (1). Jinekolojik maligniteler arasında postoperatif dönemde YB takibi en sık over kanserleri için gerekli olmaktadır. Over kanserlerinde geç bulgu vermeleri ve hormonal özellik göstermeleri nedeniyle sistemik komplikasyonlar diğer jinekolojik malignitelere oranla daha sık görülmektedir (2). Jinekolojik malignitelerde sitoredüktif cerrahilerin optimal şekilde yapılabilmesi için büyük volümde asit boşaltılması, geniş bir cerrahi tümör çıkarılması, splenektomi, üriner ve gastrointestinal trakt ya da karaciğer rezeksiyonları gerekebilir (3). Bu şekilde genişletilmiş cerrahi geçiren hastalarda mevcut medikal durumları ve intraoperatif ortaya çıkan olaylar nedeniyle postoperatif YB izlemi gerekli olabilir (2).

Kanser hastaları için hastane ve YB medikal kaynaklarının kullanılması ile mortalitenin anlamlı olarak azaltılabildiği gösterilmiştir. Ancak hastaneye ya da YB'a kabul edilen hastalarda yatış endikasyonları tartışmalıdır (4). Hastaların ameliyat sonrasında YB ihtiyacının belirlenmesi preoperatif değerlerin yanında intraoperatif olaylar ve anestezist ile cerraha bağlı kişisel yorum ve tercihlerden de etkilenebilmektedir (5).

Yoğun bakım yatakları, tüm hastane yataklarının küçük bir bölümünü oluştururken, yatak başına düşen sağlık personeli sayısı ve toplam hastane masrafları açısından en büyük paya sahiptir (6). Cerrahi YB yataklarının bir kısmı travma hastaları gibi önceden YB'a gelmesi beklenmeyen hastalar tarafından, diğer bir kısmı da YB'a gelişleri operasyon öncesinden planlanabilen yüksek riskli hastalar tarafından kullanııı. Yüksek riskli hastaların hangilerinin postoperatif YB ihtiyaçları olacağının önceden bilinebilmesi mevcut yatakların yönetimi açısından oldukça önemlidir.

Bu geriye dönük çalışmada, elektif cerrahi planlanan evre IIIIV over tümörlü hastalarda preoperatif ve intraoperatif verilerin postoperatif YB gereksinimi için ön belirleyici olarak değerini araştırdık. Hastaların cerrahi öncesi demografik verileri, laboratuvar bulguları, yandaş hastalıkları, kullandıkları ilaçları ve malignite özellikleri incelenerek, hastalarda postoperatif YB gerekliliğinin tahmin edilebilirliğini belirlemeyi amaçladık.

\section{Gereç ve Yöntem}

Başkent Üniversitesi Tıp ve Sağlık Bilimleri Araştırma Kurulu (Proje no: KA09/434) onayı alındıktan sonra Ocak 2007-Aralık 2009 tarihleri arasındaBaşkent Üniversitesi Tıp Fakültesi Ankara
Hastanesi'nde elektif şartlarda geniş cerrahi rezeksiyon geçirmiş Evre III-IV over tümörü tanılı 122 hastanın medikal ve anestezi kayıtları geriye dönük olarak incelendi. Hastalar servise (Grup Servis, $n=64$ ) ve YB'a (Grup YB, $n=58$ ) çıkanlar olmak üzere iki ayrı gruba ayırılarak değerlendirildi.

Jinekolojik diğer maligniteler nedeniyle cerrahi geçirmiş hastalar, Evre III-IV dışındaki over tümörleri ve diğer organların primer malignitelerinin eşlik ettiği hastalar çalışmaya dahil edilmedi. Incelenen dönemde gerçekleştirilen cerrahiler, anestezi uygulamaları ve YB takipleri aynı ekipler tarafından gerçekleştirildi. Ameliyatın tamamlanmasının ardından anestezi ve cerrahi ekiplerinin ortak kararı ile hastanın YB ya da servise çıkmasına karar verildi.

Hastaların verileri, değerlendirmenin daha optimal yapılabilmesini sağlamak amacıyla preoperatif, intraoperatif ve postoperatif dönemler ayıılarak kaydedildi. Preoperatif dönemde hastaların tanımlayıcı verileri (yaş, boy, ağırlık, vücut kitle indeksi (VKI)), American Society of Anesthesiologists (ASA) skorları, eşlik eden sistemik hastalıkları, kullanmakta oldukları ilaçlar, yapılan konsültasyonlar, laboratuvar değerleri, plevral mayi veya intraabdominal asit varlığı, tromboemboli varlığı, kemoterapiradyoterapi öyküleri, kanser evreleri, uygulanan premedikasyonlar, vital bulguları (sistolik-diyastolik kan basınçları, kalp atım hızı, oksijen satürasyonları, vücut sıcaklıkları) ve preoperatif pozitif inotrop intiyaçları kaydedildi. Intraoperatif dönemde uygulanan anestezi türü (genel, rejyonal) monitörizasyon tipi (noninvaziv, invaziv), vital bulgular (sistolik-diyastolik kan basınçları, kalp atım hızı, oksijen satürasyonları ve vücut sıcaklıkları), kan gazı değerleri $\left(\mathrm{pH}, \mathrm{PaO}_{2}, \mathrm{PaCO}_{2}\right.$, laktat, baz açığı), saatlik idrar miktarları, verilen sıvılar (kristaloid, kolloid), kan ve kan ürünü replasmanı ihtiyaçları, yaşanan kritik olaylar (hipotansiyon, hipertansiyon, bradikardi, taşikardi, kanama, hipoksi, arrest, ölüm), komplikasyonlar (barsak perforasyonu, karaciğer laserasyonu, mesane rüptürü, üreter yaralanması ve damar yaralanması gibi), pozitif inotrop intiyaçları ve ameliyat süreleri kaydedildi. Postoperatif dönemde ise hastaların YB ihtiyaçları ve kalış süreleri, Acute Physiology and Chronic Health Evaluation II (APACHE II) skorları, mekanik ventilasyon ihtiyaçları ve süreleri, pozitif inotrop ihtiyaçları, gelişen sorunlar (atelektazi, pnömoni, yara yeri enfeksiyonu, sepsis, derin ven trombozu, pulmoner tromboemboli, akut böbrek hasarı ve ölüm), konsültasyon gereksinimi, analjezi yöntemleri (i.m. analjezi, i.v. analjezi, i.v. hasta kontrollü analjezi (HKA), epidural HKA) ve hastanede kalış süreleri kaydedildi.

Sürekli değişkenlerin dağılımının normale yakın olup olmadığı Shapiro-Wilk testiyle araştırıldı. Gruplar arasında ortalamalar student t testi ile, ortanca değerler Mann-Whitney $U$ testi ile karşılaştırıldı. Nominal değişkenler ki-kare testiyle değerlendirildi. Tek değişkenli istatistiksel analizler sonucunda YB'da kalmayı etkileyen risk faktörleri aday risk faktörleri olarak regresyon modeline dahil edildi. Çoklu Değişkenli Illeriye Dönük Lojistik Regresyon analizi kullanılarak YB'da kalmayı belirleyen risk faktörleri tespit edildi. Her bir değişkene ait odds oranı, \%95 güven aralığı, wald istatistikleri ve önemlilik düzeyleri hesaplandı. 


\section{Bulgular}

Grup YB'nin yaş ortalaması ve ASA skorunun III-IV olma oranı daha yüksek bulundu ( $p<0,001)$. Yine Grup YB'de VKI'nin $\geq 30$ kg/m2 olması, yandaş hastalık sıklığı, preoperatif ilaç kullanımı, preoperatif metastaz ve preoperatif konsültasyon gereksinimi Grup Servis'ten daha fazla idi (tüm değerler için, $p<0,05$ ). Preoperatif vital bulgular incelendiğinde Grup YB ve Grup Servis arasında minimum ve maksimum $\mathrm{SpO}_{2}$ düzeyleri dışında $(p<0,001)$ anlamlı farklılık görülmedi (tüm değerler için, $p>0.05)$. Cerrahi öncesinde kardiyoloji veya göğüs hastalıkları bölümlerinden konsültasyon istenme sıklığı Grup YB'de daha fazlaydı ( $p=0,013$ ve $p<0,001)$. Diğer bölümlerden istenen konsültasyon sayıları iki grup arasında benzer idi ( $p>0,05)$. Premedikasyon uygulamaları gruplar arasında farklıık göstermedi (p>0,05), (Tablo 1).

Iki grup karşılaştırıldığında yandaş hastalıklardan sadece KOAH'ın anlamlı şekilde Grup YB'de daha sık olduğu gözlendi $(p=0,002)$. Diğerlerinin (koroner arter hastalığı, kalp yetersizliği, hipertansiyon, diabetes mellitus, hipotiroidi, hipertiroidi, astım, anemi, hiperlipidemi ve nörolojik hastalıklar) sıklıkları benzerdi (tüm parametreler için, p>0,05). Kullanılan ilaçlardan ise sadece kardiyak glikozid ve bronkodilatör kullanımı yönünden istatistiksel anlamlı farklılık bulundu (sırasıyla $p=0,048$ ve $p=0,005$ ). Preoperatif dönemde kardiyak glikozid veya bronkodilatör kullanan olguların tümü YB'da kalmaktaydı. Diğer kullanılan ilaçların (antihipertansifler, antidiyabetikler, antitrombotikler, antiaritmikler, antitiroidler, hipolipidemikler, tiroid hormon preparatları ve antidepresanlar) dağılımı gruplar arasında benzerdi (tüm değerler için, p>0,05).

Asit ve plevral mayi varlığı ve tümör evresinin Evre IV olması Grup YB'de anlamlı olarak daha sıktı $(p<0,001, p<0,001$ ve $p=0,002)$. Ancak, tromboemboli, kemoterapi ya da radyoterapi almak ile YB'a alınma arasında istatistiksel anlamlı bir ilişki görülmedi (tüm parametreler için, p>0,05)

Laboratuvar ölçümlerinden sodyum ve albümin düzeyleri iki grup arasında fark anlamlı idi $(p<0,001$ ve $p=0,021)$. Diğer laboratuvar ölçümleriyle YB'da kalış arasında istatistiksel olarak anlamlı birliktelik bulunmadı (tüm değerler için, p>0,05), (Tablo 2).

Gruplar arasında uygulanan anestezi şekli açısından farklılık yoktu (p>0.05). Intraoperatif parametrelerden minimum ve maksimum kalp atım hızları, kritik olay sıklığı, kritik olaylar içerisinde hipotansiyon, taşikardi veya transfüzyon gerektiren kanama sıklıkları Grup YB'de anlamlı şekilde yüksekti (tüm değerler için $p<0,001)$. Grup YB'de intraoperatif dönemde invaziv monitorizasyon daha sık uygulanmıştı $(p<0,001)$. Diğer intraoperatif özellikler değerlendirildiğinde $\mathrm{SpO}_{2}$ minimum değeri $(p=0,026)$, maksimum laktat düzeyi $(p=0,023)$, pozitif inotrop intiyacı, ameliyat süresi, kristaloid, kolloid ve eritrosit veya TDP replasmanları gruplar arasında anlamlı olarak farklı idi (tümü için $\mathrm{p}<0,001$ ), (Tablo 3).

Tablo 1. Grup Servis ve Grup YB hastalarının tanımlayııı ve klinik özellikleri ortalama \pm standart sapma veya sayı [\%]).

\begin{tabular}{|c|c|c|c|}
\hline Değişkenler & $\begin{array}{l}\text { Grup Servis } \\
\quad(n=64)\end{array}$ & $\begin{array}{c}\text { Grup YB } \\
(n=58)\end{array}$ & p değeri \\
\hline Yaş (Yıl) & $53,9 \pm 11,1$ & $63,4 \pm 9,5$ & $<0,001$ \\
\hline ASA $1-2 / 3-4$ & $62(97) / 2(3)$ & $42(72) / 16(28)$ & $<0,001$ \\
\hline Yandaş hastalık varlığı & $49(77)$ & $55(95)$ & 0,004 \\
\hline Preoperatif metastaz varlığı & $34(53)$ & $54(93)$ & $<0,001$ \\
\hline Preoperatif konsültasyon istemi & $27(42)$ & $39(67)$ & 0,006 \\
\hline En düşük sistolik kan basıncı (mmHg) & $106,7 \pm 9,8$ & $108,0 \pm 9,7$ & 0,454 \\
\hline En yüksek kan basıncı (mmHg) & $128,3 \pm 12,1$ & $130,4 \pm 10,7$ & 0,318 \\
\hline En yüksek $\mathrm{SpO}_{2}(\%)$ & $97,4 \pm 1,8$ & $96 \pm 2,1$ & $<0,001$ \\
\hline En düşük kalp hızı (atım/dak) & $75,9 \pm 9,7$ & $79,2 \pm 10$ & 0,070 \\
\hline En yüksek kalp hızı (atım/dak) & $92,9 \pm 12,7$ & $95,3 \pm 11,4$ & 0,276 \\
\hline
\end{tabular}

En yüksek kalp hızı (atım/dak) VKi; vücut kitle indeksi, ASA; American Society of Anesthesiologists, $\mathrm{SpO}_{2}$; Oksijen satürasyonu 
Tablo 2. Grup Servis ve Grup YB hastalarının cerrahi öncesi laboratuvar ölçümleri (ortalama \pm standart sapma)

\begin{tabular}{|c|c|c|c|}
\hline Değişkenler & Grup Servis $(n=64)$ & Grup YB $(n=58)$ & p değeri \\
\hline Trombosit (bin/ $\mu \mathrm{L})$ & $335,7 \pm 116,5$ & $351,7 \pm 119,5$ & 0,328 \\
\hline Kreatinin $(\mathrm{mg} / \mathrm{dL})$ & $0,75 \pm 0,30$ & $0,84 \pm 0,30$ & 0,150 \\
\hline $\mathrm{Na}^{+}(\mathrm{mmol} / \mathrm{L})$ & $139,7 \pm 2,1$ & $137,5 \pm 4,1$ & $<0,001$ \\
\hline $\mathrm{K}^{+}(\mathrm{mmol} / \mathrm{L})$ & $4,25 \pm 0,80$ & $4,25 \pm 0,60$ & 0,471 \\
\hline Total kolesterol (mg/dL) & $194,3 \pm 30,5$ & $182,7 \pm 34,7$ & 0,285 \\
\hline Trigliserid (mmol/L) & $126,3 \pm 58,1$ & $116,8 \pm 30,1$ & 0,881 \\
\hline Total bilirubin (mg/dL) & $0,54 \pm 0,30$ & $0,54 \pm 0,30$ & 0,860 \\
\hline AST (U/L) & $25,5 \pm 9,9$ & $24,7 \pm 10,7$ & 0,490 \\
\hline $\operatorname{ALT}(\mathrm{U} / \mathrm{L})$ & $20,0 \pm 12,7$ & $15,8 \pm 7,9$ & 0,089 \\
\hline CA-125 (U/mL) & $1221 \pm 2250$ & $2467 \pm 4268$ & 0,082 \\
\hline
\end{tabular}

$\mathrm{Na+}$; sodyum, K+; potasyum, Ca+2; kalsiyum, AST; aspartat aminotransferaz, ALT; alanin aminotransferaz, aPT; aktive parsiyel tromboplastin zamanı, INR; international normalized ratio, CA-125; cancer antigen125

Tablo 3. Grup Servis ve Grup YB hastalarının cerrahi öncesi ve cerrahi sırasındaki özellikleri yönünden dağıımı (ortalama \pm standart sapma veya sayı [\%])

\begin{tabular}{|c|c|c|c|}
\hline Değişkenler & Grup Servis $(n=64)$ & Grup YB $(n=58)$ & p değeri \\
\hline Genel anestezi & $63(98)$ & $57(98)$ & 1,000 \\
\hline Spinal anestezi & $0(0)$ & $1(2)$ & 1,000 \\
\hline Spinal + Epidural & $1(2)$ & $0(0)$ & 1,000 \\
\hline Genel + Epidural & $2(3)$ & $0(0)$ & 0,497 \\
\hline İnvaziv monitorizasyon uygulama & $5(8)$ & $26(45)$ & $<0,001$ \\
\hline Hipertansiyon & $9(14)$ & $8(14)$ & 0,966 \\
\hline Bradikardi & $1(1)$ & $1(2)$ & 1,000 \\
\hline Taşikardi & $4(6)$ & $22(38)$ & $<0,001$ \\
\hline Minimum $\mathrm{SpO}_{2}$ değeri & $98 \pm 1,7$ & $96,2 \pm 3,8$ & 0,026 \\
\hline Hipoksi & $2(3)$ & $4(7)$ & 0,422 \\
\hline Üreteral hasar & $2(3)$ & $1(2)$ & 1,000 \\
\hline Kristalloidler (mL) & $3041 \pm 1182$ & $4112 \pm 2168$ & $<0,001$ \\
\hline Kolloidler (mL) & $398 \pm 239$ & $617 \pm 396$ & $<0,001$ \\
\hline Kan Ürünleri & $41(64)$ & $54(93)$ & $<0,001$ \\
\hline Eritrosit süspansiyonu (ünite) & $1,1 \pm 1,2$ & $2,9 \pm 3,0$ & $<0,001$ \\
\hline Taze donmuş plazma (ünite) & $1,3 \pm 1,3$ & $2,5 \pm 1,6$ & $<0,001$ \\
\hline Ameliyat süresi (dakika) & $159 \pm 56$ & $201 \pm 68$ & $<0,001$ \\
\hline
\end{tabular}

$\mathrm{Na+}$; sodyum, K+; potasyum, Ca+2; kalsiyum, AST; aspartat aminotransferaz, ALT; alanin aminotransferaz, aPTT; aktive parsiyel tromboplastin zamanı, INR; international normalized ratio, CA-125; cancer antigen125 
Beklenebileceği şekilde postoperatif dönemde tüm komplikasyonlar (pozitif inotrop intiyacl, mekanik ventilasyon uygulanması, diğer branşlardan konsültasyon istenmesi, atelektazi, yara yeri enfeksiyonu, pnömoni veya akut böbrek yetmezliği) Grup YB'de istatistiksel olarak anlamlı derecede daha fazlaydı (tümü için $p<0,05$ ). Grup YB'de intravenöz hasta kontrollü analjezi uygulanması daha sıktı $(p<0,001)$. Hastanede kalış süreleri Grup Servis'te daha kısa bulundu $(p<0,001)$. Ölen olguların tümü Grup YB'de yer alan olgulardı ( $p=0,010)$, (Tablo 4).

Elde edilen parametrelerin çok değişkenli lojistik regresyon modelinde incelenmesiyle ileri yaş, ASA sınıfı 3-4 olması, preoperatif $\mathrm{SpO}_{2}$ 'nin düşük olması, intraoperatif taşikardi ve kan ve kan ürünü kullanılması postoperatif dönemde YB'a alınma için bağımsız risk faktörleri olarak belirlendi (Tablo 5).

\section{Tartışma}

Yoğun bakımlar, ciddi fizyolojik instabilitesi olan hastaların yaşam desteği intiyaçlarını ileri teknik imkanlar kullanılarak karşılayan monitorizasyon ve bakım üniteleridir. Klinik durumu ağır ve stabil olmayan hastalarda morbidite ve mortaliteyi iyileştirdikleri gösterilmiştir (6). Bu nedenle gerçekten YB ihtiyacı olan hastaların önceden belirlenebilmesi ve sınırlı sayıdaki YB yataklarının organizasyonu ve verimli kullanılabilmesi için önemlidir. Kritik hastalığı olan kanser hastalarının YB ünitelerine kabul edilmeleri uzun süreler tartışma konusu olmuştur. Doksanlı yıllardan önceki çalışmalarda, ileri evre kanser hastalarında mortalitenin ve tedavi masraflarının çok yüksek olması nedeniyle bu hastaların YB ünitelerine alınmalarının, sınırlı sağık kaynaklarının uygunsuz şekilde kullanılması anlamına geldiği görüşü sıklıkla gündeme gelmekteydi $(7,8)$. Ancak, son 20 yılda malignite ve organ yetmezliği tedavilerindeki gelişmeler, antikanser tedavilerdeki yenilikler, septik şok, non-invazif mekanik ventilasyon, akut solunum yetmezliği, sedasyon ve ventilatörden ayırma gibi konuların daha iyi yönetimi ile kritik hastalığı olan kanser hastalarında daha yüz güldürücü sonuçlar alınabildiği gözlenmektedir $(9,10)$. Yoğun bakımlarda yapılan hızlı ve etkin müdahalelerle birçok komplikasyon ya da fizyolojik dekompansasyon, sistemik hasar oluşmasına firsat verilmeden çözümlenebilmektedir. Capuzzo ve ark. YB'da tedavi gören hastaların daha erken taburcu olduğunu ve sosyal ve fiziksel hayatlarına daha hızlı dönebildiklerini bildirmişlerdir (11). Jinekolojik hastalar arasında YB intiyacı en çok fazla olan grup malignite hastalarıdır ve bu intiyaç genellikle engellenemeyen ve beklenmeyen bir durumdur. Over kanseri hastalarında YB kalışını gerektiren önemli nedenlerden biri majör cerrahi sonrası postoperatif yakın takip intiyacıdır. Postoperatif dönemde kanama ve önceki tıbbi durum bozukluğu sıkıkla ciddi morbiditeyle ilişkilidir (12).

Evre III-IV over kanseri bulunan ve elektif olarak geniş cerrahi rezeksiyon yapılan hastalarda ameliyat sonrasında YB intiyacı için ön belirleyici faktörleri incelediğimiz çalıșmamızda ileri yaș, ASA sınıfı 3-4 olması, preoperatif $\mathrm{SpO}_{2}$ 'nin düşük olması, intraoperatif taşikardi ve kan ve kan ürünü kullanılması postoperatif dönemde YB'a alınma için bağımsız risk faktörleri olarak belirlendi.

Hastaların yaș, VKI, eşlik eden sistemik hastalıkları ya da organ yetersizlikleri gibi fiziksel özellikleri, ameliyat sonrası dönemde yaşayacakları dekompansasyon durumlarını tolere edebilmeleri açısından önem taşır (13-16). Artan yaşla beraber organların

Tablo 4. Grup Servis ve Grup YB hastalarının postoperatif özelliklerinin incelenmesi (ortalama \pm standart sapma veya sayı [\%])

\begin{tabular}{lccc}
\hline Değişkenler & Grup Servis (n=64) & Grup YB (n=58) & p değeri \\
\hline Pozitif inotrop ihtiyacı & $0(0)$ & $5(9)$ & $18(31)$ \\
Mekanik ventilasyon & $0(0)$ & $45(78)$ & $<, 022$ \\
Konsültasyon istemi & $21(33)$ & $38(66)$ & $<, 001$ \\
Postoperatif sorun varlığı & $7(11)$ & $17(30)$ & $<0,001$ \\
Atelektazi & $3(5)$ & $13(22)$ & $<, 001$ \\
Yara yeri enfeksiyonu & $3(5)$ & $4(7)$ & 0,004 \\
Pnömoni & $0(0)$ & $10(17)$ & 0,048 \\
Akut böbrek hasarı & $0(0)$ & $53(91)$ & $<0,001$ \\
Intravenöz hasta kontrollü analjezi & $11(17)$ & $2(3)$ & $<0,001$ \\
Tromboemboli & $0(0)$ & $3(5)$ & 0,224 \\
Kardiyak sorunlar & $1(2)$ & $3(5)$ & 0,345 \\
Sepsis & $0(0)$ & $6(10)$ & 0,105 \\
Ölüm & $0(0)$ & $22 \pm 12$ & 0,010 \\
Hastanede kalış süresi (gün) & $11 \pm 4$ & $2,2 \pm 2,7$ & $<0,001$ \\
Yoğun bakım kalış süresi (gün) & - & $13,4 \pm 6,5$ & - \\
APACHE II skoru & - & -
\end{tabular}

APACHE; Acute Physiology and Chronic Health Evaluation 
Tablo 5. Çoklu değişkenli ileriye dönük lojistik regresyon analizine göre yoğun bakım gereksinimi için bağımsız risk faktörleri

\begin{tabular}{lccc}
\hline Değişkenler & Odds Oranı & $\begin{array}{c}\text { \%95 Güven Aralığı } \\
\text { Alt Sınır-Üst Sınır }\end{array}$ & p değeri \\
\hline Yaş & 1,1 & $1,0-1,1$ & 0,036 \\
VKI >30kg/m² & 1,1 & $0,9-1,2$ & 0,113 \\
ASA III - IV & 6,2 & $1,1-35,7$ & 0,044 \\
İntraoperatif hipotansiyon & 3,2 & $0,5-19,6$ & 0,199 \\
İntraoperatif taşikardi & 8,6 & $1,6-47,6$ & 0,013 \\
Intraoperatif kan ve kan ürünü kullanımı & 7,7 & $1,3-47,6$ & 0,026 \\
Preoperatif en düşük SpO 2 & 1,3 & $1,0-1,7$ & 0,050 \\
İntraoperatif toplam sıvı replasmanı & 1,0 & $1,0-1,1$ & 0,186 \\
\hline
\end{tabular}

VKi; vücut kitle indeksi, ASA; American Society of Anesthesiologists, $\mathrm{SpO}_{2}$; oksijen saturasyonu

fonksiyon kapasiteleri ve strese yanıt yetenekleri azalır. lleri yaş organ fonksiyonlarının azalması için tek başına artmış bir risk faktörü iken, eşlik eden sistemik hastalık varlığı organ fonksiyonlarını daha da azaltacak ve risk oranını arttıracaktır (13). Brooks ve ark. YB'a alınan over karsinomu nedeniyle cerrahi geçirmiş hastalarda ileri yaşın YB'da ve toplam hastanede kalış süresini doğrudan etkilediğini belirlemişlerdir (14). Ileri dönük yapılan başka bir çalışmada ise YB'da kalma süresi ve mortalite üzerine ileri yaşın önemli bir etken olduğu ancak etkileyen faktörün öncelikle hastalığın ciddiyeti olduğu belirtilmiştir (15). Ayrıca, obezite de eşlik eden birçok hastalığın zemininde yer almaktadır. Berchtold ve ark. obezitenin (VKI >30 kg/m²), diabetes mellitus, hipertansiyon, bazı kanser türleri ve iskemik kalp hastalığı için risk faktörü olduğunu bildirmişlerdir (16).

Bizim çalışmamızda da ameliyat sonrasında YB'a alınan hastalar ile servise alınan hastalar arasında yaş, eşlik eden sistemik hastalıklar ve ilaç kullanımı öyküsü, ASA skorları, VKI'nin $>30 \mathrm{~kg} / \mathrm{m} 2$ olması gibi faktörler istatistiksel olarak anlamlı farklı bulundu. Bu değerleri lojistik regresyon analizi ile değerlendirdiğimizde de yalnızca ileri yaş ve ASA skoru yüksekliğinin YB'a kabulde anlamlı olduğunu gördük. Bağlantılı olarak YB'a alınan hastalarda, ameliyat öncesinde özellikle kardiyoloji ve göğüs hastalıkları bölümleri olmak üzere diğer bölümlerden istenen konsültasyon sayısı ve kardiyak glikozid ve bronkodilatatör kullanım öyküsü servise alınan gruptan istatistiksel olarak anlamlı derecede daha fazlaydı.

Akut solunum yetmezliği ile YB'a yatan $\mathrm{KOAH}^{\prime}$ ı hastaların prognozu kötüdür. Hastane içi mortalite \%6-26 arasında değişiklik gösterir. Bu olguların takiplerinde 2 yıllık mortalite \%40 olarak bildirilmektedir (17). Preoperatif dönemde akciğer parenkimi ile ilgili ya da primer ya da sekonder restriktif nedenlere bağlı solunumsal sorunları bulunan hastalarda postoperatif solunumsal komplikasyonlar artar (18). Çalışmamızda KOAH'ı bulunan hastalarda preoperatif $\mathrm{SpO}_{2}$ 'nin düşüklüğü mevcuttu ve bu hastalarda preoperatif YB'a kabulün anlamlı olarak arttığı görüldü. Lojistik regresyon analizinde de preoperatif dönemde $\mathrm{SpO}_{2}$ düşüklüğü postoperatif YB'a kabul için bağımsız bir risk faktörü olarak belirlendi.
Diaz-Montes ve ark. yaşın $\geq 63$ olmasını, intraoperatif $\geq 5 \mathrm{~L}$ kristaloid verilmesini ve serum albümin düzeyinin $<3,5 \mathrm{~g} / \mathrm{dL}$ olmasını cerrahi YB'da 48 saatten uzun kalmak için risk faktörleri olarak belirlemişler, ek olarak serum albümin seviyesinin $\geq 3,5$ g/dL olmasının da YB'da kalış süresini \%77 oranında kısalttığını bildirmişlerdir (19). Biz, preoperatif laboratuvar değerlerine baktığımızda hemoglobin $(\mathrm{Hb})$ düşüklüğünün, serum sodyum $(\mathrm{Na}+)$ düşüklüğünün ve serum albümin seviyesi düşüklüğünün yoğun bakıma kabulde rol oynayabilecek anlamlı sonuçları olduğunu gördük. Aynı zamanda, bizim hastalarımızda da operasyon esnasında kristaloid ve kolloid replasmanlarının YB'a alınan hastalarda, serviste izlenen hastalardan daha fazla yapıldığını belirledik.

Intraoperatif dönemde cerrahiye bağlı sıvı kaybının yanı sıra eksilen asit Sıvısı ve kanamalar önemli intravasküler volüm kaybına neden olur ve reaktif olarak hipotansiyon ve taşikardi tabloya hakim olur. Sitoredüktif cerrahi nedeniyle oluşan inflamatuvar cevap üçüncü boşluklara sıvı kaçışını daha da artırır $(20,21)$. Chi ve ark. sitoredüktif cerrahi prosedürlerde operasyon süresinin ve kan kaybının diğer abdominal cerrahi prosedürlere oranla arttığını ve kan kaybının > 1000 mL ve cerrahi sürenin >327 dakika olmasının planlanmamış yoğun bakım ihtiyacı ile ilişkili olduğunu bildirmişlerdir (22). Black ve ark., kan transfüzyonu ihtiyacı ile sağkalım arasında ilişki olmadığını bildiriken (23), Amir ve ark., artmış intraoperatif kan kaybı ve preoperatif asit miktarlarının postoperatif YB kalış süresini artırdığını ve servise ya da YB'a alınan hastalarda ameliyat sürelerinin benzer olduğunu bildirmişlerdir (2). Bizim çalışmamızda YB'a alınan hastalarda operasyon süresi, intraoperatif yaşanan kritik olay sayısı, kanama miktarları, kan ve kan ürünü replasmanı intiyacı, intraoperatif pozitif inotrop intiyacı ve laktat düzeyleri istatistiksel olarak anlamlı şekilde daha fazlaydı. Ayrıca minimum ve maksimum kalp atım hızları ve sistolik ve diyastolik kan basınç ölçümlerinde anlık değişkenlikler YB grubunda daha fazla görüldü. Lojistik regresyon analiziyle intraoperatif kan ve kan ürünü kullanımı ve taşikardi gelişmesi YB'a kabul için anlamlı risk faktörleri olarak belirlendi.

Evre IV over karsinomunda asit, uzak organ metastazları ya da plevral efüzyon görülebilir ve bu durum sağkalım ve prognozu 
etkiler $(24,25)$. Bağırsak rezeksiyonu ileri evre over kanseri ve bağırsak obstrüksiyonu bulunan hastalarda sıkça uygulanan bir cerrahidir. Bu hastaların durumu, gastrointestinal sistemi normal çalışanlara göre daha morbid seyretmektedir $(1,2)$. Çalışmamızda, YB grubunda preoperatif metastaz varlığı (özellikle bağırsak, karaciğer ve omentum metastazı), asit ve/veya plevral efüzyon varlığı ve tümör evresinin III-IV olması anlamlı olarak yüksekti.

Önceki çalışmalarda sitoredüktif cerrahi sırasında çeşitli organlarda oluşan travmalar sonucu primer veya sekonder komplikasyonlar bildirilmiştir. Bu komplikasyonlar, postoperatif tedavi ve kemoterapi sürecini etkileyerek hastaların YB ve hastanede kalış sürelerini ve mortalitelerini etkiler $(14,26)$. Bizim çalışmamızda intraoperatif komplikasyon gelişmesi (bağırsak perforasyonu, mesane rüptürü, karaciğer laserasyonu gibi) ve YB'a alınma arasında doğrudan anlamlı bir ilișki saptanmadı. Ancak bu komplikasyonlar indirekt katkı sağlamıs olabilirler.

Ileri evre over tümörlerinde gerçekleştirilen sitoredüktif cerrahi prosedürler gastrointestinal anastomozları da içerebilen büyük cerrahiler olarak, yaygın peritoneal inflamasyon ve sistemik inflamatuar cevaba neden olurlar. Postoperatif dönemde komplike olmayan vakalar sıklıkla ilk 24 saatte ekstübe edilirken, komplike vakalar uzun süre mekanik ventilasyon desteğine intiyaç duyabilir (20). Cerrahi sonrasında solunum yetmezliğinin nedeni genellikle nonkardiyojenik pulmoner ödem, akut akciğer hasarı (ALI) ya da daha ciddi akut respiratuar distres sendromudur (ARDS). Cerrahi sonrasında hastalarda görülen ateş ve akciğer infiltrasyonları genellikle pnömoni tanısıyla takip edilir, fakat bu hastalarda asıl neden büyük olasııkla akut akciğer hasarıdır. Ancak bu hastalarda insidans, risk faktörleri ve sonuçları gösteren ve değerlendiren geniş çaplı ileri dönük bir çalışma bulunmamaktadır (26). Akut akciğer hasarı, cerrahi travmaya bağlı doku hasarına ikincil gelişen sistemik inflamatuar yanıt sonucu oluşur. Sepsiste, masif hemoraji ve kan transfüzyonlarında, perioperatif fazla sıvı verilenlerde ve hemodinamik olarak stabil olmayan hastalarda daha sık görülür (20).
Çalışmamızda, postoperatif dönemde bir veya birden fazla komplikasyon yaşanması, özellikle pnömoni, atelektazi, yara yeri enfeksiyonu ve akut böbrek hasarı $(\mathrm{ABH})$ gelişmesi gibi komplikasyonlar ve pozitif inotrop gereksinimi YB intiyacı ile ilişkiliydi. Yine postoperatif dönemde diğer bölümlerden konsültasyon istemi sayısı, özellikle infeksiyon hastalıkları, göğüs hastalıkları ve endokrinoloji bölümlerinden, YB hastalarında daha fazlaydı.

Abu Rustum ve ark. primer sitoredüksiyon operasyonu sonrası transfüzyon ihtiyacı olan ileri evre over, fallop tüpü veya peritoneal karsinomalı hastalarda transfüzyon almayanlara göre venöz tromboz ve/veya pulmoner emboli riskinin arttığını bildirmişlerdir (27). Bizim çalışmamızda benzer bir sonuca ulaşamadık.

Postoperatif ağrı takibinde mortalite ve majör morbiditeler (miyokard infarktüsü, pnömoni, atelektazi) kadar hasta memnuniyeti, yaşam ve derlenme kalitesi de günümüzde gittikçe önem kazanmaktadır (28). Hastalar arasında ve her hastanın kendi içindeki geniş farklııklardan dolayı analjezik intiyaçları, serum ilaç seviyelerindeki değişiklikler (özellikle intramusküler enjeksiyonlar) ve uygulamadaki gecikmeler uygun olmayan ağrı tedavisine neden olmaktadır. Tüm bunlar göz önüne alındığında hasta kontrollü analjezi (HKA) opioid analjeziklerin uygulanmasında ve bireysel farklılıkları ortadan kaldırmada etkili bir yöntem olarak görülmektedir $(29,30)$. Bizde YB'da takip edilen hastaların postoperatif ağrı kontrolünün, intravenöz HKA ile daha yüksek oranda yapıldığını belirledik, ama bir karşılaştırma yapmadık.

Çalışmamızda postoperatif dönemde meydana gelen ölümlerin tamamı YB'da takip edilen hastalarda gözlendi ve YB'a alınan hastaların toplam hastanede kalış süreleri istatistiksel açıdan anlamlı olarak daha uzun bulundu.

Sonuç olarak, evre III-IV over tümörü nedeniyle cerrahi geçiren hastalarda postoperatif dönemde yoğun bakıma alınma oranları hastaların yaş ortalamaları, ASA skorları, preoperatif minimum $\mathrm{SpO}_{2}$ değerleri, intraoperatif taşikardi sıklıkları ve intraoperatif kan ve kan ürünü transfüzyonu intiyaçları ile ilişkili bulunmuştur. Ancak bu verilerin ileridönük düzende ve geniş çaplı çalışmalarla desteklenmesi gerektiği kanaatindeyiz.

\section{Kaynaklar}

1. Leath CA 3rd, Kendrick JE 4th, Numnum TM, Straughn JM Jr, Rocconi RP, Sfakianos GP, et al. Outcomes of gynecologic oncology patients admitted to the intensive care unit following surgery: A university teaching hospital experience. Int J Gynecol Cancer 2006;16:1766-9.

2. Amir M, Shabot MM, Karlan BY. Surgical intensive care unit care after ovarian cancer surgery: An analysis of indications. Am J Obstet Gynecol 1997;176:1389-93
3. Eisenkop SM, Spirtos NM, Friedman RL, Lin WC, Pisani AL, Perticucci S. Relative influences of tumor volume before surgery and the cytoreductive outcome on survival for patients with advanced ovarian cancer: A prospective study. Gynecol Oncol 2003:90:390-6.

4. Studnicki J, Schapira DV, Straumfjord JV, Clark RA, Marshburn J, Werner DC. A national profile of the use of intensive care by medicare patients with cancer. Cancer 1994;74:2366-73.
5. Zeyneloglu P, Pirat A, Candan s, Canikli Ş, Erkaya Ç, Karademinoğulları O, ve ark. Kalça protez cerrahisi yapılan hastaların yoğun bakım ünitesine kabul önbelirleyicileri. Yoğun Bakım Dergisi 2006;6:108-11

6. Rosenthal GE, Sirio CA, Shepardson LB, Harper DL, Rotondi AJ, Cooper GS. Use of intensive care units for patients with low severity of illness. Arch Intern Med 1998;158:1144-51

7. Carlon GC. Admitting cancer patients to the intensive care unit. Crit Care Clin 1988:4:183-91. 
8. Darmon M, Azoulay E. Critical care management of cancer patients: Cause for optimism and need for objectivity. Curr Opin Oncol 2009;21:318-26.

9. Kress JP, Christenson J, Pohlman AS, Linkin DR, Hall JB. Outcomes of critically ill cancer patients in a university hospital setting. Am J Respir Crit Care Med 1999;160:1957-61.

10. Pene F, Percheron $S$, Lemiale V, Viallon $V$, Claessens YE, Marque S, et al. Temporal changes in management and outcome of septic shock in patients with malignancies in the intensive care unit. Crit Care Med 2008;36:690-6.

11. Capuzzo M, Bianconi M, Contu P, Pavoni V, Gritti G. Survival and quality of life after intensive care. Intensive Care Med 1996;22:947-53.

12. Heinonen S, Tyrvainen E, Penttinen J, Saarikoski S, Ruokonen E. Need for critical care in gynaecology: A population-based analysis. Crit Care 2002;6:371-5.

13. Rodgers A, Walker N, Schug S, McKee A, Kehlet $\mathrm{H}$, van Zundert A, et al. Reduction of postoperative mortality and morbidity with epidural or spinal anaesthesia: Results from overview of randomised trials. BMJ 2000;321:1493.

14. Brooks SE, Ahn J, Mullins CD, Baquet CR. Resources and use of the intensive care unit in patients who undergo surgery for ovarian carcinoma. Cancer 2002;95:1457-62.

15. Margulies DR, Lekawa ME, Bjerke HS, Hiatt JR, Shabot MM. Surgical intensive care in the nonagenarian. No basis for age discrimination. Arch Surg 1993;128:753-6; discussion 756-8.
16. Berchtold $P$, Jorgens $V$, Finke $C$, Berger $M$. Epidemiology of obesity and hypertension. Int J Obes 1981;5 suppl 1:1-7.

17. Ornek T, Tor M, Altin R, Atalay F, Geredeli E, Soylu O, et al. Clinical factors affecting the direct cost of patients hospitalized with acute exacerbation of chronic obstructive pulmonary disease. Int J Med Sci 2012;9:285-90.

18. Fernandez-Perez ER, Sprung J, Afessa B, Warner DO, Vachon CM, Schroeder DR, et al. Intraoperative ventilator settings and acute lung injury after elective surgery: $A$ nested case control study. Thorax 2009;64:121-7.

19. Diaz-Montes TP, Zahurak ML, Bristow RE. Predictors of extended intensive care unit resource utilization following surgery for ovarian cancer. Gynecol Oncol 2007; 107:464-48.

20. Ahmed S, Oropello JM. Critical care issues in oncological surgery patients. Crit Care Clin 2010;26:93-106.

21. Schmidt C, Moritz S, Rath S, Grossmann E, Wiesenack C, Piso P, et al. Perioperative management of patients with cytoreductive surgery for peritoneal carcinomatosis. J Surg Oncol 2009;100:297-301.

22. Chi DS, Zivanovic O, Levinson $\mathrm{KL}$, Kolev V, Huh J, Dottino J, et al. The incidence of major complications after the performance of extensive upper abdominal surgical procedures during primary cytoreduction of advanced ovarian, tubal, and peritoneal carcinomas. Gynecol Oncol 2010;119:38-42.

23. Black D, lasonos A, Ahmed H, Chi DS, Barakat RR, Abu-Rustum NR. Effect of perioperative venous thromboembolism on survival in ovarian, primary peritoneal, and fallopian tube cancer. Gynecol Oncol 2007;107:66-70.
24. Dowdy SC, Loewen RT, Aletti G, Feitoza SS, Cliby W. Assessment of outcomes and morbidity following diaphragmatic peritonectomy for women with ovarian carcinoma. Gynecol Oncol 2008;109:303-7.

25. Eisenhauer EL, D'Angelica MI, AbuRustum NR, Sonoda Y, Jarnagin WR, Barakat RR, et al. Incidence and management of pleural effusions after diaphragm peritonectomy or resection for advanced mullerian cancer. Gynecol Oncol 2006;103:871-7.

26. Kehoe SM, Eisenhauer EL, Abu-Rustum NR, Sonoda Y, D'Angelica M, Jarnagin WR, et al. Incidence and management of pancreatic leaks after splenectomy with distal pancreatectomy performed during primary cytoreductive surgery for advanced ovarian, peritoneal and fallopian tube cancer. Gynecol Oncol 2009;112:496-500.

27. Abu-Rustum NR, Richard S, Wilton A, Lev G, Sonoda Y, Hensley ML, et al. Transfusion utilization during adnexal or peritoneal cancer surgery: Effects on symptomatic venous thromboembolism and survival. Gynecol Oncol 2005;99:320-6.

28. Wu CL, Richman JM. Postoperative pain and quality of recovery. Curr Opin Anaesthesiol 2004;17:455-60.

29. Macintyre PE. Safety and efficacy of patient-controlled analgesia. Br J Anaesth 2001;87:36-46.

30. Wakerlin G, Larson CP, Jr. Spousecontrolled analgesia. Anesth Analg 1990;70:119. 